International Journal of Current Advanced Research

ISSN: O: 2319-6475, ISSN: P: 2319 - 6505, Impact Factor: SJIF: 5.995

Available Online at www.journalijcar.org

Volume 6; Issue 3; March 2017; Page No. 2680-2683

DOI: http://dx.doi.org/10.24327/ijcar.2017.2683.0075

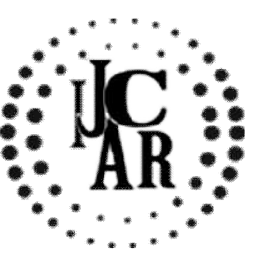

Research Article

\title{
STUDY OF BACTERIA AVAILABLE IN SMOKED FISH PREPARED FROM PROCESSED CONDITION BY INDIGENOUS METHOD
}

\author{
Sudakshina Das ${ }^{1}$ and Pradyut Saikia ${ }^{2}$ \\ ${ }^{1}$ Department of Zoology, D.H.S.K College, KC Gogoi Path Dibrugarh 786001, Assam, India \\ ${ }^{2}$ J.R.F, Institutional Level Biotech Hub, D.H.S.K College, KC Gogoi Path Dibrugarh 786001, Assam, India
}

\section{A R T I C L E I N F O}

\section{Article History:}

Received $20^{\text {th }}$ December, 2016

Received in revised form $24^{\text {th }}$ January, 2017

Accepted $6^{\text {th }}$ February, 2017

Published online $28^{\text {th }}$ March, 2017

\section{Key words:}

Smoked Fish, Staphylococcus sp., Escherichia sp, Klebsiella sp and Salmonella sp

\begin{abstract}
A B S T R A C T
Fish is one of the important sources of animal protein. It has essential nutrients required for supplementing both infants and adults. Fishes are more easily digestible than other animal proteins, so it is usually recommended to patients with digestive disorders for both children and aged people. Fish is highly perishable. It is readily susceptible to chemical and microbial deterioration leading to economic loss, reduction in quality of the fishes and wastage. In the present study three kinds of fishes are selected for isolation and identification of bacteria in smoked type and the fishes are- Puntius, Mystus \& Colisa. From the present study it was observed that four strains were found in the smoked fishes. Total ten (10) isolates are from smoked fishes. Out of which five (5) isolates were Staphylococcus sp., one (1) isolates was Escherichia sp, three (3) were Klebsiella sp and 1 Salmonella sp were present. Identification of the isolates was confirmed by various biochemical tests and Gram staining tests. The study concluded that the possibility of biochemical method is more in smoked fishes than raw fishes. The smoked fishes may be contaminated during the period of Drying or smoked or may be contaminated for preservation of drying the fishes for a long time in humid condition in Assam.
\end{abstract}

Copyright $₫ 2017$ Sudakshina Das and Pradyut Saikia. This is an open access article distributed under the Creative Commons Attribution License, which permits unrestricted use, distribution, and reproduction in any medium, provided the original work is properly cited.

\section{INTRODUCTION}

Fish is one of the important sources of animal protein. It has essential nutrients required for supplementing both infants and adults. Fishes are more easily digestible than other animal proteins, so it is usually recommended to patients with digestive disorders for both children and aged people. Fish protein is relatively cheaper and richer in lysine and different sulphur containing amino acids than other livestock protein like chicken, meat, mutton etc thus suitable for complementing high carbohydrate diets of our area. Fish is highly perishable. It is readily susceptible to chemical and microbial deterioration leading to economic loss, reduction in quality of the fishes and wastage [1]. Fish is available in most market as fresh, smoked, dried, canned, chilled or frozen. The flesh of the fishes deteriorates more rapidly in comparison to that of mutton, beef and pork. Fish spoilage occurs due to three factors- bacterial action, chemical actions and enzymatic actions. Spoilage due to chemical action occurs in fatty fish only. The oil of this fish is oxidized by atmospheric $\mathrm{O}_{2}$ resulting in discoloration and bad odour of the fishes.

*Corresponding author: Sudakshina Das Department of Zoology, D.H.S.K College, KC Gogoi Path Dibrugarh 786001, Assam, India
Large number of fishes is spoil due to its own digestive enzymes which remains active even after the death of the fishes and softens the flesh by autolysis.

Bacteria find a good medium for the development due to high moisture content in flesh. Fishes gets cuts during catching and leads to haemorrhage and this provides ideal condition for bacterial activities [2]. When the fishes are carried from the processing centers to the market centers, raw and smoked fishes often get contaminated with bacteria and other microorganisms during transportation, improper handling and dumping at unhygienic sites. Also during handling of fishes, the natural flora of the environment will be contaminated with organisms associated with man, such as members of Enterobacteriaceae and Staphylococcaceae which can grow well at $30^{\circ}-37^{\circ}$ [3]. Fish drying is one of the key processes in fish preservation for longer period of time. The prime reason for fish drying is to reduce the moisture content of the nonaqueous material to such a level that insufficient water remains to stop the growth of the micro-organisms which feed on it. This level is also sufficiently low to stop chemical degradation. It is necessary to dry the fish as quickly as possible from 45 to $60 \%$ moisture content to $10 \%$ moisture or less [3]. After the discovery of fire, early humans found that fish hung up over the fire dried more quickly and acquires a delicious flavor when kept over a smoke. From the time of early humans smoking has been practiced. In Assam it is 
practiced in every village. Before smoking, fishes are clean and wash properly and little amount of salt is sprinkle over it. Smoking process entails the use of firewood and it is traditionally performed in a thatched hut, in which a raised platform with bamboo mats (chaloni) is spread across. The fish for smoking are placed on the mats for a period of 24 to $48 \mathrm{hrs}$. In the pits beneath the platform, firewood's are placed and burnt. Smoke evolving from firewood increases the temperature of the hut and dries up the fishes [4]. Various ethnic communities are present in Assam such as Kachari, Motok, Missing, Boro, Dimasa, Garo, Ahom, Rabha, Chutia etc who prepares smoked fishes in their home. Smoked fishes are used by them in various ways. Many of these communities (kachari, missing, motok ahom etc) make hukoti (Assamese dish) by grinding the smoked fishes [5]. Numsing is normally prepared during monsoon season when the trash fish and arum are available in the villages in plenty [4]. Some people wrap hukoti in banana leaves to cook and then consume it. Also in dried bamboo sunga (Bamboo tube), hukoti are kept preserved for longer use by covering the mouth of the tube (sunga) with dried banana leaves. Smoked fishes can be simply fried and consume. Some mixes taro leaves with smoked fishes and then grind them and preserved. Microbes have existed on earth for billions of years and were here long before plant and animal life began. The bacteria are able to multiply in nature under a wide range of various conditions. They can grow in extreme environments that no other living organisms can tolerate. The climate of Assam is typically 'tropical monsoon rainfall' type with high level of humidity which ranges from 60 to 70 percent in summer and in winter humidity reaches up to 90 percent. The relative humidity in Assam is one of the Highest in India. Hence bacterial growth is a common feature in all kinds of food stuff including fishes. In the present study three kinds of fishes are selected for isolation and identification of bacteria in smoked type and the fishes are- Puntius, Mystus \& Colisa.

\section{METHODS}

Description of Study Area: Dibrugarh is situated in the South Bank of Brahmaputra River in Upper Assam. Dibrugarh district extends from $27^{\circ} 5^{\prime} 38^{\prime \prime} \mathrm{N}$ to $27^{\circ} 42^{\prime} 30^{\prime \prime} \mathrm{N}$ latitude and $94^{\circ} 33^{\prime} 46^{\prime \prime} \mathrm{E}$ to $95^{\circ} 29^{\prime} 8^{\prime \prime} \mathrm{E}$ longitude. Dibrugarh district have only one sub-division which is situated in the eastern part of Assam. The Dibrugarh district is surrounded by a part of Dhemaji district and Lakhimpur district in the north, part of Sivasagar district and Arunachal Pradesh in the south, Tinsukia district in the East and Sivasagar district in the West. The district occupies an area of $3381 \mathrm{sq} \mathrm{km}$. Santipara and Overbridge area are situated in the northern part of Dibrugarh town. These two areas are mainly famous for availability of dry and raw fishes. Raw fishes are collected from the river Dihing and Sesa and transported to the Santipara and Overbridge market. Thus some of the dry fishes are prepared from these raw fishes and produces in the market.

Collection of sample: Fish samples were collected from two places - Over bridge fish market, \& Santipara fish market of Dibrugarh town. The Fish samples were collected in a plastic bags and were immediately isolated in the Laboratory for the bacterial culture.

Preparation of Sample: The collected fish samples were cut into small pieces using sterile scissor. These small pieces are then put in the petri disc containing agar media after it gets
harden.Peptone water method: Each sample was pounded in a sterile porcelain mortar. 1gram of each sample was aseptically introduced into $9 \mathrm{ml}$ of peptone water In a test tube, to give 10-1 dilution and two subsequent serial dilutions (10-2 and 10-3) this was prepared in test tubes by transferring $1 \mathrm{ml}$ to $9 \mathrm{ml}$ of peptone water.

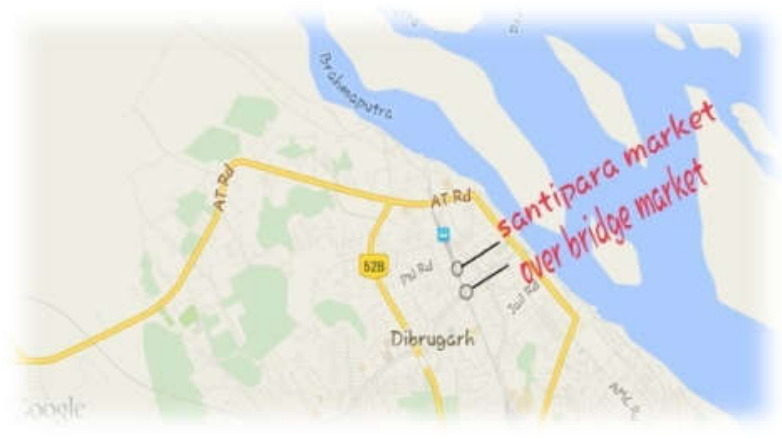

Fig 1 Maps of Dibrugarh showing Santipara market and Overbridge market https://www.google.co.in/maps Dated: 25.06.2015.

Preparation of Media: Preparation of Nutrient agar and Nutrient broth is required for the isolation of bacteria. The media was prepared in sterilized glass beaker by dissolving 28.00 grams of Nutrient Agar to $1000 \mathrm{ml}$ of distilled water and vortexing was done to mix the solution completely. The media is heat for 10-15 minutes in oven. Sterilization of media was done by autoclaving at 15 psi pressure at 121 o $\mathrm{C}$ for 15 minutes. After the agar solution was hardened, with the help of the loop, bacterial colony is picked and then streaked on the plate in a quadrant wise. After that the Petri dishes were labeled and sealed and then incubated at $37^{\circ} \mathrm{C}$ for 24 hours. Colonies with different colors were seen on the plate and then proceed for the next step i.e. Sub Culture technique.

Sub Culture Technique to obtain pure culture: Different colors were developed which represents different microorganisms. These microorganisms were mixed-culture which was used to prepare the sub-culture. The inoculating loop was burned in the Bunsen flame until it turns red hot. The loop was then allowed to cool for a few seconds. A single colony was picked from the culture plate and then streaked on the plate by an inoculating loop gently in a quadrant wise. The plate was then incubated at $37^{\circ} \mathrm{C}$ for 24 hours. Sub-cultures are to be prepared for several times to obtain pure culture. When the sub-culture consists of a single colony with no other overlapping colonies, then it is confirmed as pure culture. The pure culture was then transferred into the broth media. In nutrient broth the organisms remain intact.

Identification of Microorganisms: Selective/Differential media were used such as MacConkey agar medium, Eosine Methylene Blue agar medium, and Mannitol salt agar medium to differentiate and identify bacterial Isolates. Selective / Differential media plates were incubated at $37^{\circ} \mathrm{C}$ for 24 hours from the pure culture plates that was grown on nutrient agar medium. The isolates were then biochemically analyzed for the activities of Catalase, MR-VP test, Starch hydrolysis, Phenylalanine Agar test, Tryptone test, Nitrate test, Indole production and Citrate utilization [6-8]. Gram Staining tests were used to separate the gram positive and gram negative bacteria. The tests were used to identify the isolates according to Bergey's Manual of Systematic Bacteriology [9]. 


\section{RESULT AND DISCUSSIONS}

Four strains were isolated from smoked fishes. The result of this study shows that the bacteria isolated from the smoked fishes are Escherichia sp., Enterobacter sp., Salmonella sp., and Staphylococcus sp. Identification and characterization of isolated bacteria were performed on the basis of microscopic morphological study such as shape, arrangement, colonies etc. and biochemical tests such as indole production test, methyl red, Voges-proskauer test, citrate utilization test, catalase test and MacConkey test growth at $37^{\circ} \mathrm{C}$. Selective media were prepared and the isolated bacteria were inoculated under sterilized conditions incubated at $37^{\circ} \mathrm{C}$ for 24 hours and the results were recorded following the handbook of Bergey's Manual of Systematic Bacteriology. The isolates identified were Escherichia sp., Enterobacter sp., Salmonella sp., and Staphylococcus sp.

In Figure 3: Enterobacter spp. was identified by Methyl red and Voges Proskauer test. In VP test Enterobacter spp. shows red pigmentation on addition of omera's reagent.

Table no 1 No. of colonies formed from smoked fish samples (in pure culture)

\begin{tabular}{cccc}
\hline Sl.no & Fish species & Colony formed & Colony colour \\
\hline 1. & Tengra & 4 & Yellow, Pink, White \& Cream white \\
2. & Pystus) & 3 & White, Yellow \& Orange \\
3. & Colisa & 3 & White, Yellow \& Cream white
\end{tabular}

Table No 2 Morphological characteristics of the Bacteria identified by Gram stain from smoked fish samples:

\begin{tabular}{llccc}
\hline Organisms & $\begin{array}{c}\text { Colony } \\
\text { Colour }\end{array}$ & $\begin{array}{c}\text { Gram } \\
\text { Staining }\end{array}$ & $\begin{array}{c}\text { Microscopy } \\
\text { result }\end{array}$ & $\begin{array}{c}\text { Morphological } \\
\text { shape }\end{array}$ \\
\hline Organism 1 & $\begin{array}{c}\text { Cream } \\
\text { white }\end{array}$ & + & Cocci Shaped & Cluster form \\
Organism 2 & Pink & - & Rod shaped & Cluster form \\
Organism 3 & White & - & Rod shaped & Chain form \\
Organism 4 & Orange & - & Cocci shaped & Cluster form \\
Organism 5 & Yellow & + & Rod shaped & Chain form \\
\hline
\end{tabular}

In Fig 2 \& 3; $S$ aureus was identified on Mannitol Salt Agar Medium due to presence of yellow color caused by change of $\mathrm{pH}$ of phenol red by fermentating Mannitol Sugar where as $S$ epidermidis was identified as it does not fermented mannitol and pink color remains.

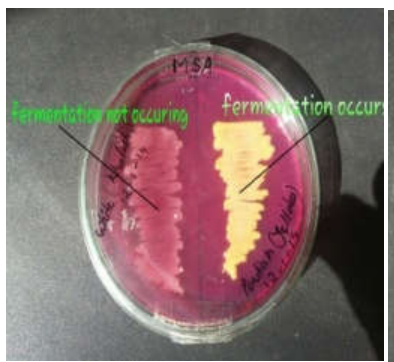

Fig 2

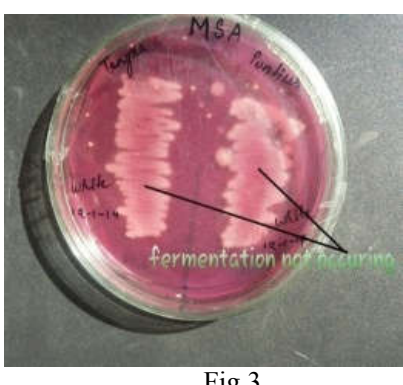

Fig 3
In Fig 4; E. coli of pure culture was obtained on Nutrient Agar and identified on EMB Agar medium by observing blue black with dark centres with green metallic sheen.

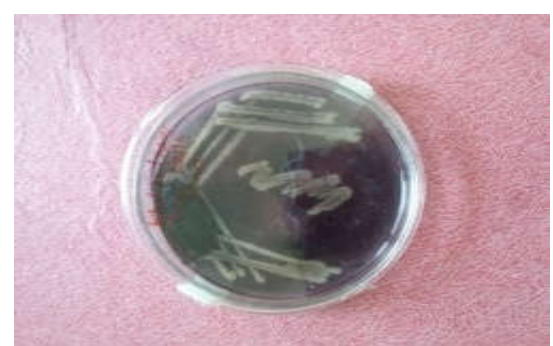

Fig 4

In Fig 5; Enterobacter spp. was identified by Methyl red and Voges Proskauer test. In VP test Enterobacter spp. shows red pigmentation on addition of omera's reagent

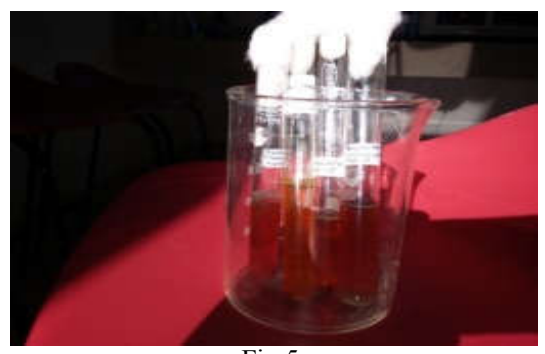

Fig 5

In Fig 6; Salmonella spp. was identified on Simmon Citrate Agar due to utilization of citrate as a carbon source, the enzyme citrase hydrolyzes citrate into oxaoloacetic acid and acetic acid. The oxaloacetic acid is then hydrolyzed into pyruvic acid and $\mathrm{CO}_{2}$. If $\mathrm{CO}_{2}$ is produced, it reacts with components of the medium to produce an alkaline compound (e.g. $\mathrm{Na}_{2} \mathrm{CO}_{3}$ ). The alkaline $\mathrm{pH}$ turns the $\mathrm{pH}$ indicator (bromthymol blue) from green to blue.
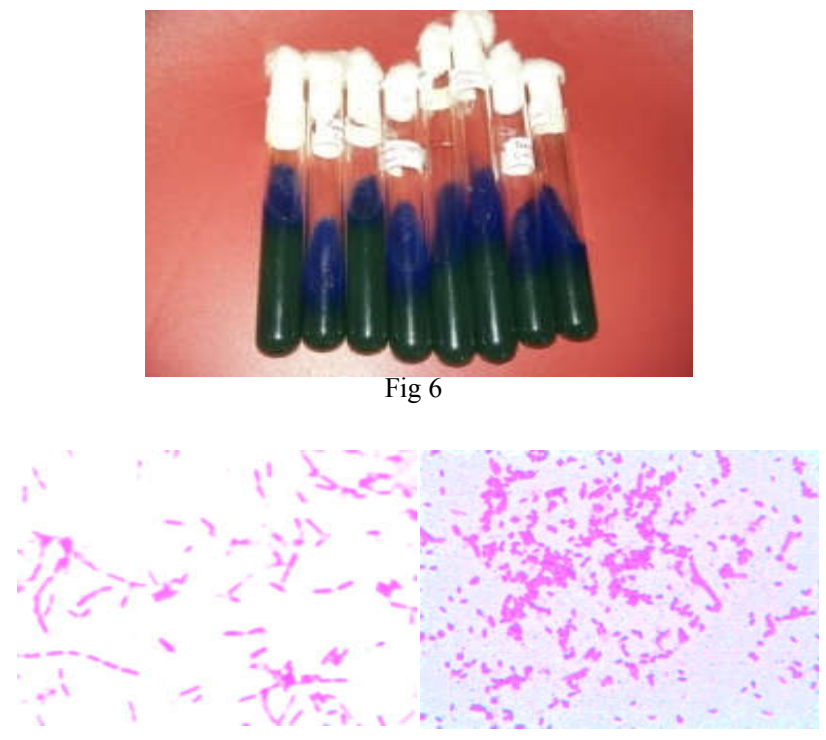

Fig 7 (i)

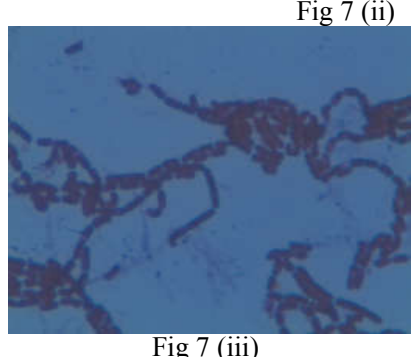

Fig 7 (iii)

Figure 7 Microscopic view of (i) E. coli (ii) Enterobacter sp. \& (iii) Salmonella sp. by gram staining techniques. 
Table 3 Biochemical Analysis of (smoked) fish samples:

\begin{tabular}{cccccc}
\hline Tests & Isolate 1 & Isolate 2 & Isolate 3 & Isolate 4 & Isolate 5 \\
\hline Gram Stain & $+\mathrm{ve}$ & $+\mathrm{ve}$ & $-\mathrm{ve}$ & $-\mathrm{ve}$ & $-\mathrm{ve}$ \\
Indole & $-\mathrm{ve}$ & $-\mathrm{ve}$ & $+\mathrm{ve}$ & $-\mathrm{ve}$ & $-\mathrm{ve}$ \\
MR & $-\mathrm{ve}$ & $-\mathrm{ve}$ & $+\mathrm{ve}$ & $-\mathrm{ve}$ & $-\mathrm{ve}$ \\
VP & $-\mathrm{ve}$ & $-\mathrm{ve}$ & $-\mathrm{ve}$ & $+\mathrm{ve}$ & $-\mathrm{ve}$ \\
MSA & $+\mathrm{ve}$ & $-\mathrm{ve}$ & $-\mathrm{ve}$ & $-\mathrm{ve}$ & $-\mathrm{ve}$ \\
EMB & $-\mathrm{ve}$ & $-\mathrm{ve}$ & $+\mathrm{ve}$ & $-\mathrm{ve}$ & $-\mathrm{ve}$ \\
Catalase & $+\mathrm{ve}$ & $+\mathrm{ve}$ & $+\mathrm{ve}$ & $+\mathrm{ve}$ & $-\mathrm{ve}$ \\
Starch & $-\mathrm{ve}$ & $-\mathrm{ve}$ & $-\mathrm{ve}$ & $-\mathrm{ve}$ & $-\mathrm{ve}$ \\
Citrate & $-\mathrm{ve}$ & $-\mathrm{ve}$ & $-\mathrm{ve}$ & $-\mathrm{ve}$ & $+\mathrm{ve}$ \\
PA Agar & $-\mathrm{ve}$ & $-\mathrm{ve}$ & $-\mathrm{ve}$ & $-\mathrm{ve}$ & $-\mathrm{ve}$ \\
McConkey & $-\mathrm{ve}$ & $-\mathrm{ve}$ & $+\mathrm{ve}$ & $-\mathrm{ve}$ & $-\mathrm{ve}$ \\
Identified & Staphylococ & Staphyloco & Escheric & Enterob & Salmonella \\
bacteria & cus aureus & copidermidis & hia coli & acter spp. & spp. \\
\hline
\end{tabular}

\section{SUMMARY AND CONCLUSIONS}

From the present study it was observed that four strains were found in the smoked fishes. Total ten (10) isolates are from smoked fishes. Out of which five (5) isolates were Staphylococcus sp., one (1) isolates was Escherichia sp, three (3) were Klebsiella sp and 1 Salmonella sp were present. Identification of the isolates was confirmed by various biochemical tests and Gram staining tests.

The above finding of isolates are similar to the isolates identify by Sultana et al. in 2010 [10] in their research "Isolation and Identification of bacteria from Dried Fishes collected from different areas of Bangladesh". Similarliy Adeyemi et al. [1] "Effect of Moringa oleifera marinade on microbial stability of smoked-dried African catfish (Claria $s$ gariepinus)" also observed namely Staphylococcus sp. Bacillus sp. Escherichia sp. Therefore those isolates are common in smoked fishes in different country.

The presence of small numbers of Staphylococcus in fish products is not a serious problem but food poisoning may occur if the product is handled carelessly during processing resulting in multiplication of the organism. It causes a range of illness from minor skin infections such as pimples, scalded skin syndromes and abscesses, to life threatening diseases such as pneumonia, meningitis, toxic shock syndrome. Staphylococci are also known to be a cause of bacterial conjunctivitis in human eye.

In humans virulent strains of Escherichia sp., can cause various diseases such as gastroenteritis, urinary tract infection, and neonatal meningitis. In rare cases, virulent strains are also responsible for haemolytic-uremic syndrome, peritonitis, mastitis, and septicaemia and gram negative pneumonia.

Salmonella sp. is facultative intracellular pathogens. Many infections are due to ingestion of salmonella contaminated food. They can be divided into two groups- Thyhoidal and Nonthyphoidal Salmonella serovars. Nonthyphoidal serovars are more common and usually causes self limiting gastrointestinal diseases. Thyhoidal serovars include Salmonella typhi and Salmonella paratyphi which are adapted to humans and not occur in other animals.
Enterobacter sp is a widely pathogenic bacterium that causes opportunistic infections. It is generally found in the human gastrointestinal tract and does not generally cause diseases in healthy individual. The study concluded that the possibility of biochemical method is more in smoked fishes than raw fishes. The smoked fishes may be contaminated during the period of Drying or smoked or may be contaminated for preservation of drying the fishes for a long time in humid condition in Assam. Precaution should be taken in handling, preparation and preservation of such fish food product for better use in future to reduced health risks.

\section{Acknowledgement}

We are thankful to D.B.T, Govt. of India for providing financial aid to establish Institutional Level Biotech Hub of D.H.S.K College where the experiments were conducted.

\section{References}

1. Adeyemi .D.K., Ahmed El-Imam. M.A., Dosunmu .O.O. and Lawal O.K..(2013) "Effect of Moringa oleifera marinade on microbical stability of smokeddried aferican catfish (Claria s gariepinus) "Ethiopian Journal of Environmental Studies and Management Vol. 6 No. $1: 104-108$.

2. A Hand book on Economic Zoology by Jawaid Ahsan and Subhas Prasad Sinha. 314 pages. S Chand Publication.

3. Moshood. A. Yusuf and Tengku Haziyamin Abdul Tengku Abdul Hamid (2012). "Isolation and Identification of Bacteria in Retailed Smoked Fish, Within Bauchi Metropolis" IOSR Journal of Pharmacy and Biological Sciences Volume 3, Issue, 0105.

4. AU Muzaddadi (2013). Naturally evolved fermented fish products of North east India (Seedal and Shedal) A comparative Study. Indian Journal of Natural products and resources. Vol 4 (2). Pp 170-177.

5. Dutta.N.N., Borah S. and Baruah D. (2012). Traditional gears used for capturing and preservation of fish by Mishing community of northern bank of the Brahmaputra River, Assam, India. Science Vision. MIPOGRASS. Vol 12. Issue No. 4.

6. C.H. Collins, P.M. Lyne, and G.M. Grange, "Collins and Lyne Microbiolo-gical methods," (6th Edition), Butterworth, London, 1989.

7. J.B. Harold, "Microbiological Applications," Laboratory Manuals in General Microbiology (8th Edition), McGraw - Hill Higher Education, 2002.

8. D. Claus, and R.C.W Berkeley, Genus Pseudomonas. In: Bergey's Manual of Systematic Bacteriology (Vol 1, Ed.): Sneath, P.H.A., Mair, N.S. and Sharpe, M.E., pp. 140-219, Baltimore, Williams and wilkins, 1986.

9. H.K. Zaved, M. Rahman Mizanur, M. Rahman Mashir, A. Rahman, S.M.Y. Arafat, and M.S. Rahman, "Isolation and characterization of effective bacteria for solid waste degradation for organic manure KMITL," Sci. Tech. J. 8, pp. 44-55, 2008.

10. Sultana. N., Siddique. P.M., Farhana.Z., Dina.A.M. and Uddin I.M (2010) " Isolation and Identification of bacteria from Dried Fishes collected from different ares of Bangladesh". Int. J. BioRes. 2 (9): 01-05. 